\title{
Long-range Atmospheric Transport of Polycyclic Aromatic Hydrocarbons is Worldwide Problem - Results from Measurements at Remote Sites and Modelling
}

\author{
Gerhard Lammel, ${ }^{1,2} *$ Alice Dvorská, ${ }^{1}$ Jana Klánová, ${ }^{1}$ Jiři Kohoutek, ${ }^{1}$ \\ Petr Kukučka, ${ }^{1}$ Roman Prokeš ${ }^{1}$ and Aissa M. Sehili ${ }^{3}$ \\ ${ }^{1}$ Masaryk University, Research Centre for Toxic Compounds in the Environment, Kamenice 3, 62500 Brno, Czech Republic \\ ${ }^{2}$ Max Planck Institute for Chemistry, Hahn-Meitner-Weg 1, 55128 Mainz, Germany \\ ${ }^{3}$ Max Planck Institute for Meteorology, Bundesstr. 53, 20146 Hamburg, Germany \\ * Corresponding author: E-mail: lammel@ recetox.muni.cz \\ Tel/Fax: +420-54949-4106
}

Received: 28-01-2015

\begin{abstract}
Despite the fact that the occurrence of polycyclic aromatic hydrocarbons (PAHs) in the atmospheric environment has been studied for decades the photochemistry, deposition and, consequently, the long-range transport potential (LRTP) are not well understood. The reason is gas-particle partitioning (GPP) in the aerosol, its sensitivity to temperature and particulate phase composition, and sampling artefacts', and reactivity's sensitivities towards particulate phase composition. Furthermore, most PAHs are subject to re-volatilisation upon deposition to surfaces (multihopping). Levels and sources of 2-6-ring unsubstituted PAHs were studied in remote environments of Europe, Africa and Antarctica. Global atmospheric transport and fate of 3-5-ring PAHs were simulated under various scenarios of photochemistry and GPP. GPP influences drastically the atmospheric lifetime, compartmental distributions and the LRTP of PAH. Mid latitude emissions seem to reach the Arctic but not the Antarctic.
\end{abstract}

Keywords: aerosol, atmospheric modelling, free troposphere, Arctic, Antarctic, Africa

\section{Introduction}

Polycyclic aromatic hydrocarbons (PAHs) are unavoidable by-products of any kind of combustion, in particular incomplete combustion processes. Therefore, these substances are ubiquitous in the polluted atmospheric environment in the $\mathrm{ng} \mathrm{m}^{-3}$ concentration range. ${ }^{1}$ The gaseous state is predominant for the lighter relative molecular mass PAHs, while the substances with more than 4 rings are preferentially associated with the aerosol particles. ${ }^{2-3}$ Gas-particle partitioning is significant for many PAHs (so-called semivolatility, expected for saturation vapour pressures in ambient air in the range $\mathrm{p}_{\text {sat }}=10^{-6}-10^{-2} \mathrm{~Pa}^{4}$ ). In terms of water and organics solubility they span a considerable wide range of properties, i.e. 3-4 orders of magnitude, but less than with regard to vapour pressure ( 9 orders of magnitude; Table 1).

In a wider sense, the substance class also encompas- ses alkylated, partly oxygenated and other substituted PAHs, besides the so-called parent PAHs. ${ }^{1,5}$

The relevance of PAHs is given by their potential to form carcinogenic and mutagenic metabolites and, partly, by being carcinogenic themselves. ${ }^{2,9-10}$ Among atmospheric trace chemical substances, PAHs probably form the class most harmful to human health. ${ }^{11}$ One parent PAH, benzo(a)pyrene (BAP), is considered as an important substance because of its toxicity (carcinogenicity) and a criteria pollutant in many countries. BAP and at least some other parent PAHs are bioaccumulative and therefore discussed as persistent organic pollutants (POPs) in the UNEP POP Convention. The entire substance class is considered as POP under the Arhus Protocol amended to the Convention on LongRange Transboundary Air Pollution (CLRTAP).

Resistance to photochemical degradation, obviously a condition for long-range atmospheric transport, in fact, is not well understood: In the gas-phase the reactions with 
Table 1: Physico-chemical properties and degradability in air of 17 parent 2-6 ring PAHs (i.e. 16 USEPA priority PAHs and benzo(e)pyrene) at 298 K. ${ }^{2,6-7}$ Estimated values (EPIWIN model ${ }^{8}$ ) in lack of experimental data are given in brackets.

\begin{tabular}{|c|c|c|c|c|c|}
\hline & $\begin{array}{c}\mathbf{p}_{\text {sat }}{ }^{(a)} \\
(\mathbf{P a})\end{array}$ & $\begin{array}{c}\mathbf{K}^{\mathbf{H}(\mathbf{b})} \\
\left(\mathbf{M} \mathbf{a t m}^{-1}\right)\end{array}$ & $\log K_{o w}{ }^{(c)}$ & $\begin{array}{c}\mathrm{k}_{\mathrm{ig} \mathrm{OH}}{ }^{(d)} \\
\left(10^{-12} \mathrm{~cm}^{3}\right. \\
\left.\text { molec }^{-1} \mathrm{~s}^{-1}\right)\end{array}$ & $\begin{array}{c}\mathrm{k}_{\mathrm{ip} \mathrm{OH}}(\mathrm{e}, \mathrm{f}) \\
\left(10^{-12} \mathrm{~cm}^{3}\right. \\
\left.\text { molec }^{-1} \mathrm{~s}^{-1}\right)\end{array}$ \\
\hline Naphthalene (NAP) & $1.0 \times 10^{1}$ & 2.3 & 3.37 & $22(22)$ & 5.0 \\
\hline Acenaphthylene (ACY) & $8.9 \times 10^{-1}$ & 8.8 & 4.07 & $110(75)$ & \\
\hline Acenaphthene (ACE) & $2.9 \times 10^{-1}$ & 5.4 & 3.92 & $100(67)$ & \\
\hline Fluorene (FLN) & $8.0 \times 10^{-2}$ & 10.4 & 4.18 & $16(9)$ & 3.1 \\
\hline Phenanthrene (PHE) & $1.5 \times 10^{-2}$ & 23.6 & 4.60 & $13(13)$ & \\
\hline Anthracene (ANT) & $8.0 \times 10^{-4}$ & 17.7 & 4.50 & $17(40)$ & 4.4 \\
\hline Fluoranthene (FLT) & $1.2 \times 10^{-3}$ & 113 & 5.22 & $50(29)$ & \\
\hline Pyrene (PYR) & $6.0 \times 10^{-4}$ & 84 & 5.18 & $(50)$ & 3.1 \\
\hline Benzo(a)anthracene (BAA) & $2.8 \times 10^{-5}$ & 83 & 5.61 & & 5.6 \\
\hline Chrysene (CHR) & $8.4 \times 10^{-5}$ & 191 & 5.91 & $(50)$ & 5.0 \\
\hline Benzo(b)fluoranthene (BBF) & $6.7 \times 10^{-5}$ & 1522 & 6.12 & (16) & \\
\hline Benzo(k)fluoranthene (BKF) & $1.3 \times 10^{-8}$ & 1712 & 6.84 & $(54)$ & 3.5 \\
\hline Benzo(e)pyrene (BEP) & $7.4 \times 10^{-7}$ & 3333 & 6.44 & $>4.3(50)$ & 4.7 \\
\hline Benzo(a)pyrene (BAP) & $7.3 \times 10^{-7}$ & 2188 & 6.50 & $3.5(50)$ & 4.1 \\
\hline Indeno(1,2,3-c,d)pyrene (IPY) & $1.3 \times 10^{-8}$ & 2874 & 6.58 & (64) & \\
\hline Dibenz(a,h)anthracene (DBA) & $1.3 \times 10^{-8}$ & 7092 & 6.50 & $(50)$ & \\
\hline $\operatorname{Benzo}(\mathrm{g}, \mathrm{h}, \mathrm{i})$ perylene (BPE) & $1.3 \times 10^{-8}$ & 3021 & 6.63 & $(87)$ & 5.9 \\
\hline
\end{tabular}


the hydroxyl radical and ozone limit the parent PAHs' atmospheric residence times to hours or days at most (Table $1^{2-3,5}$ ). In the particulate phase, however, PAHs may undergo long-range transport and reach pristine areas in high altitudes and latitudes. ${ }^{12-15}$ Obviously, rate coefficients for particle bound PAHs determined in the laboratory tend to overestimate atmospheric degradation, most likely as a consequence of matrix effects which so far could not be mimicked in laboratory experiments, i.e. shielding against oxidant attack. ${ }^{16-17}$

\section{Experimental}

\section{1. Sampling and Chemical Analysis}

Sites selected were in remote environments of Europe (Mt. Zugspitze $47^{\circ} 25^{\prime} \mathrm{N} / 10^{\circ} 59^{\prime} \mathrm{E}, 2670 \mathrm{~m}$ a.s.l.), Africa (Mt. Kenya, $0.0^{\circ} \mathrm{N} / 37.12^{\prime} \mathrm{E}, 3678 \mathrm{~m}$, Molopo Nature Reserve 25 $54^{\prime} \mathrm{S} / 22^{\circ} 54^{\prime} \mathrm{E}$, Barberspan $26^{\circ} 32^{\prime} \mathrm{S} / 25^{\circ} 36^{\prime} \mathrm{E}$ ) and Antarctica (Ekström shelf ice, $70^{\circ} 44^{\prime} \mathrm{S}, 8^{\circ} 25^{\prime} \mathrm{W}$ ), as well as one site in the central European rural environment (Košetice $49^{\circ} 34^{\prime} \mathrm{N} / 15^{\circ} 05^{\prime} \mathrm{E}, 534 \mathrm{~m}$ ). PAHs were collected in the atmospheric gaseous and particulate phases using various active high and middle volume samplers (Digitel, Graseby-Anderson, 68 and $12 \mathrm{~m}^{3} \mathrm{~h}^{-1}$, respectively) equipped with one quartz fibre filter (QFF) and 1-2 polyurethane foam (PUF) plugs in series. Size-resolved samples were collected using high-volume sampling and a 6stage cascade impactor. Passive air sampling (applied for the study of influences at African sites) relies on gas diffusion to a sorbent (PUF disk ${ }^{18}$, effective sampling rate 4-7 $\mathrm{m}^{3} \mathrm{~h}^{-1}$ ). Small particles, because of their diffusivity, are collected, too (uncharacterized sampling efficiency). Snow samples were collected by ejection into borosilicate glass bottles using a movable rod. PAHs were extracted by automated solid-phase microextraction (SPME, polydimethylsiloxane-divinylbenzene fibre at $60^{\circ} \mathrm{C}$, direct immersion $^{19}$ ). The SPME extraction efficiency is low (underestimates) for 4-6 ring PAHs.

All active and passive air (QFF and PUF) samples were extracted with dichloromethane in an automatic extractor (Soxhlet). Surrogate recovery standards were spiked on each PUF and QFF prior to extraction. The volume was reduced after extraction under a gentle nitrogen stream at ambient temperature, and fractionation achieved on a silica gel column. Samples were analyzed by gas chromatography coupled with mass spectrometry. The sampling and analytical methodology, including QA was described elsewhere. ${ }^{19-21}$ Detection and quantification limits were controlled by both laboratory and field blanks. ${ }^{21-22}$

\section{2. Meteorological Analysis}

Regional and global information about air parcel origin was derived from back-trajectory statistics. The regional provenance of advected air was determined by three-dimensional 96 h-back-trajectories (HYSPLIT mo$\mathrm{de}^{23}$ ). Trajectories were calculated usually 4-hourly (24hourly for the study of deposition in Antarctica), with various arrival height, $200-750 \mathrm{~m}$ above ground. This level ensures that the trajectory starts in the mixing layer of the atmosphere. Time weighting is used to account for the influence of dispersion and deposition on trace components abundances and to quantify the ground source loading, a continuous measure for the influence of surface emissions. ${ }^{24-25}$ Individual samples were allocated to žair sheds', i.e. the area or region of air mass passage during the sampling period. For tracking air masses back $>10$ and up to $20 \mathrm{~d}$ a Lagrangian particle dispersion model (FLEXPART model ${ }^{26}$ ) was used. The fraction of parcels above and below the boundary layer height was budgeted and used to identify samples of free tropospheric as opposed to boundary layer air. ${ }^{21}$

\section{3. Global Multicompartmental Modelling}

The model used is based on the atmosphere general circulation model ECHAM5 with simplified atmospheric chemistry and a dynamic aerosol sub-model $\left(\mathrm{HAM}^{27}\right)$. Two-dimensional ground compartments, i.e. the ocean mixed surface layer (spatio-temporally varying in depth) and single layers representing vegetation surfaces and topsoil are coupled such that multicompartmental cycling (deposition, volatilisation) is described. The PAHs behave similarly in the ground compartments upon deposition from gas or particulate phase. Uptake of PAHs into leaves and other parts of vegetation is ignored. The model has been described in detail. ${ }^{28-29}$

PAH kinetics in the particulate phase is not sufficiently understood. ${ }^{5}$ A sensitivity analysis suggests that the heterogeneous reaction of PAH with ozone is effectively limiting atmospheric lifetime and long-range transport. ${ }^{30}$ In this study, heterogeneous reactions are neglected. Several models for the processes determining gasparticle partitioning were tested in separate substance scenarios. The time step used was $30 \mathrm{~min}$ and the horizontal resolution $\approx 2.8^{\circ} \times 2.8^{\circ}$ with 19 levels in the vertical between 1000 and $10 \mathrm{hPa}$. ANT, FLT and BAP have been studied under each three scenarios of atmospheric degradation and gas-particle partitioning. The model simulations were initialized by sea-surface temperature distributions according to present-day climate and run over $10 \mathrm{yr}$.

Emissions were compiled based on emission factors in 27 major types of combustion technologies, scaled to 141 combustion technologies and their global distribution as of $1996\left(1^{\circ} \times 1^{\circ}\right)$ according to fuel type and the $\mathrm{PM}_{1}$ emission factor. ${ }^{31}$ The emissions were entried uniformly throughout the entire simulation time. Scenarios tested: adsorption ('AD', i.e. according to the Junge empirical relationship ${ }^{32}$ ), absorption in organic matter and adsorption to soot $^{33}$ without ('OB') and with ('DP') degradation in the atmospheric particulate phase. 


\section{Results and Discussion}

\section{1. Observations}

\section{1. 1. Central Europe and Free Troposphere Over Europe}

A pronounced seasonality is found: Both a stronger emission source (heating season) and a weaker chemical sink (photo-chemistry) contribute to higher abundances in winter. It had been stressed ${ }^{34-35}$ that, influenced by domestic burning sources, PAHs' concentrations can be higher at a rural than at an urban site. Winter-time PAH peak levels are 1-2 orders of magnitude higher at boundary layer sites in central Europe than summer minima (Fig. 1).

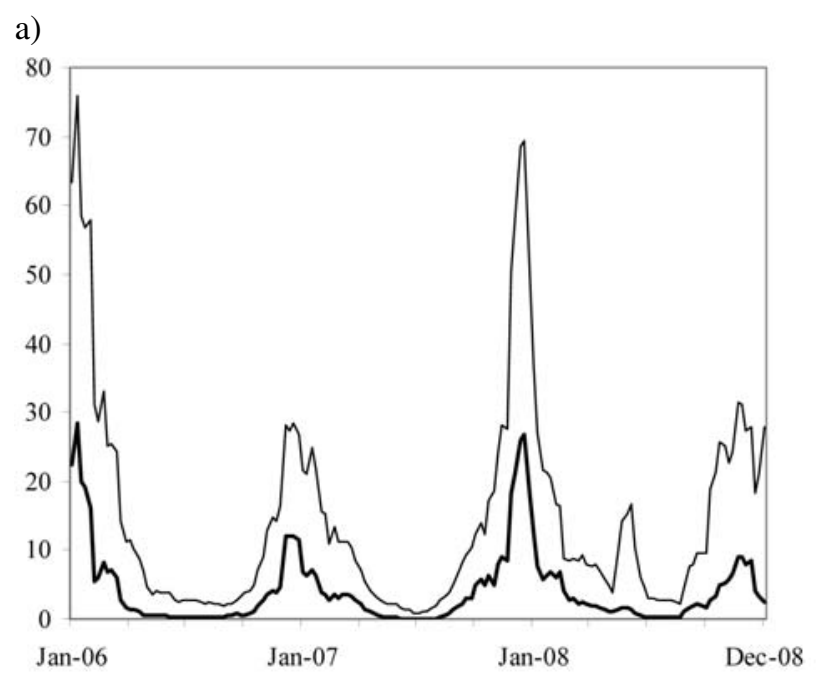

b)

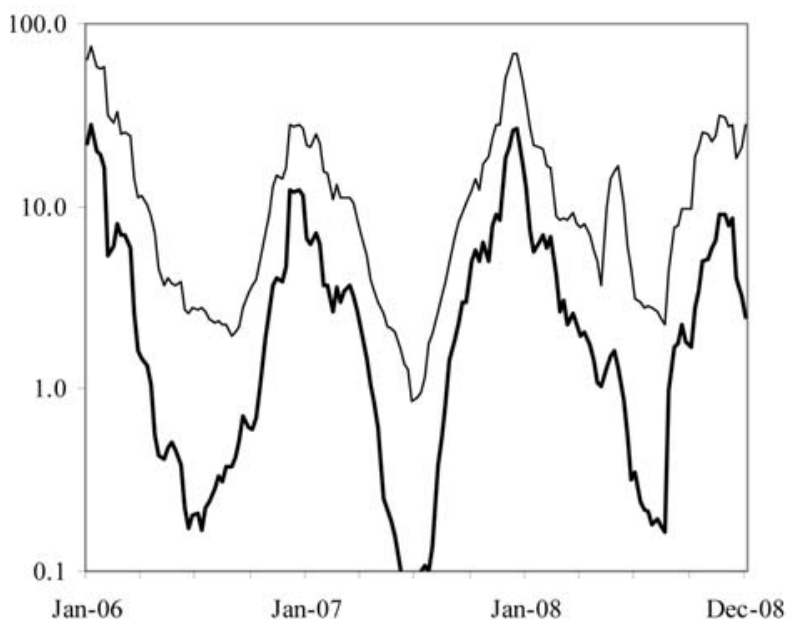

Fig. 1. 2006-2008 time series of total (sum of gas and particulate phases; thin line) and particulate phase (bold line) PAH concentration in air ( $\mathrm{ng} \mathrm{m}^{-3}$ ) in Košetice, Czech Republic, plotted (a.) linearly and (b.) logarithmically. Sum of 15 species (i.e. 16 USEPA priority PAHs without NAP), gliding monthly mean of weekly $24 \mathrm{~h}$ samples. ${ }^{10}$
At Mt. Zugspitze the total PAHs level observed (sum of gas and particulate phases) was $1.0(0.35-2.5) \mathrm{ng}$ $\mathrm{m}^{-3}$ in winter (2007-08) and $0.07(0.05-0.16) \mathrm{ng} \mathrm{m}^{-3}$ in summer (2007; sum of 15 species (i.e. 16 USEPA priority PAHs without NAP) addressed. ${ }^{21}$ Interestingly, the levels were higher in free troposphere air than in boundary layer air, which indicates resistance to photochemical degradation during transport in air. Obviously, the lifetime of PAHs can exceed 20 days in the free troposphere, despite elevated $\left(\approx 100 \mu \mathrm{g} \mathrm{m}^{-3}\right)$ ozone.

PHE and PYR accounted for $>90 \%$ of the PAH mass, which certainly indicates relative photochemical stability of these (mostly) gaseous compounds. Also, $\mathrm{BEP} /(\mathrm{BEP}+\mathrm{BAP})>0.66$ indicates aged air, as $\mathrm{BAP}$ should be degrading faster than its isomer $\mathrm{BEP}^{36}$ (see also values of $\mathrm{k}_{\mathrm{iOH}}$ in Table 1 ), as this ratio $\approx 0.5$ close to sources, as reflected by the data from the Brno area urban and rural sites (so-called diagnostic ratio ${ }^{37}$ ).

Apart from primary sources, PAHs may be re-emitted upon atmospheric deposition. Re-suspended dust (or other coarse particulate matter) and air-soil exchange could constitute such secondary sources. Air-soil exchange is occurring, ${ }^{22,38-39}$ despite sorption of PAHs to accumulation in soils. The significance of this process as a local or regional PAH source has not been assessed so far.

\section{1. 2. Boundary Layer and Free Troposphere Over Africa}

At the high mountain site Mt. Kenya the total PAHs level observed was $0.3-0.6 \mathrm{ng} \mathrm{m}^{-3}$ and at two savannah sites (Molopo and Barberspan, Rep. of South Africa) it was $0.5-1.4 \mathrm{ng} \mathrm{m}^{-3}$ in 2008; sum of 15 species (i.e. 16 USEPA priority PAHs without NAP) addressed ${ }^{40}$ ), hence, well below levels found at European background sites. The analysis of potential source areas and advection paths (3D back-trajectories) suggests that the available chemical kinetic data would lead to unplausibly high concentrations in continental source areas. It is concluded that current knowledge overestimates degradation of (at least) some 4ring PAHs during atmospheric transport. A modelling study $^{30}$ showed that the contribution of vegetation fires to exposure to PAHs in Africa is probably $>10 \%$, but cannot be quantified due to lack of knowledge with regard to both emission factors and photochemistry.

\section{1. 3. Deposition in Antarctica}

PAH concentrations in snow on the Ekström shelf ice were found within the range of 26-197 $\mathrm{ng} \mathrm{L}^{-1}$. The most prevailing substances were determined to be NAP, 1and 2-methyl-NAP, ACY, ACE and PHE with NAP accounting for an overall mean of $82 \%$ of total addressed PAH.

The depositional flux was highest for periods with high frequency of air mass passage over close sources and 
lowest for air sheds which seemingly encompassed sources distributed over almost the entire continent. ${ }^{19}$ Potential emission sources of PAHs are stations and ships, both stronger in summer. The distance to the sources (ships and research stations) in this region was found to control the snow PAH concentrations. There was no indication for intercontinental transport or marine sources, i.e. southern mid latitude emissions apparently have not reached the Antarctic in 2003-05.

\section{2. Global Multicompartmental Modelling}

The model simulations show that gas-particle partitioning in air influences drastically the atmospheric cycling, total environmental fate (e.g. compartmental distributions) and the long-range transport potential (LRTP) of the substances studied. The largest fractions of the total environmental burden is predicted to reside in soils and vegetation $(85-99 \%)$, less in ocean $(0.9-11 \%)$ and atmosphere (0.3-3.6\%; Fig. 2). ${ }^{29}$ Comparison with observed levels indicate that degradation in the particulate phase must be slower than in the gas-phase (exclusion of the assumptions made under the DP scenario). Furthermore, the levels of the semivolatile PAHs ANT and FLT at high latitudes and a European mid latitude site cannot be explained by partitioning due to adsorption alone, but point to both absorption into organic matter and adsorption to black carbon (soot) to determine gas-particle partitioning. Global modelling, therefore, suggests that the Arctic is receiving PAHs emitted in mid latitudes.

Long-range transport of PAHs is enhanced to some extent by multi-hopping. Volatilisation from ground exceeds deposition over dry parts of the continents and some sea regions at least seasonally. ${ }^{29}$

\section{Conclusions}

The results of both field observations and modelling suggest that PAH is undergoing long-range atmospheric transport including to remote continental regions, the world ocean and the Arctic. Gas-particle partitioning in air influences drastically the atmospheric cycling, total environmental fate (e.g. compartmental distributions) and the LRTP.

For coherent large-scale modelling of PAHs, knowledge gaps with regard to gas-particle partitioning and chemical kinetics (reactions with ozone and $\mathrm{NO}_{2}$, besides
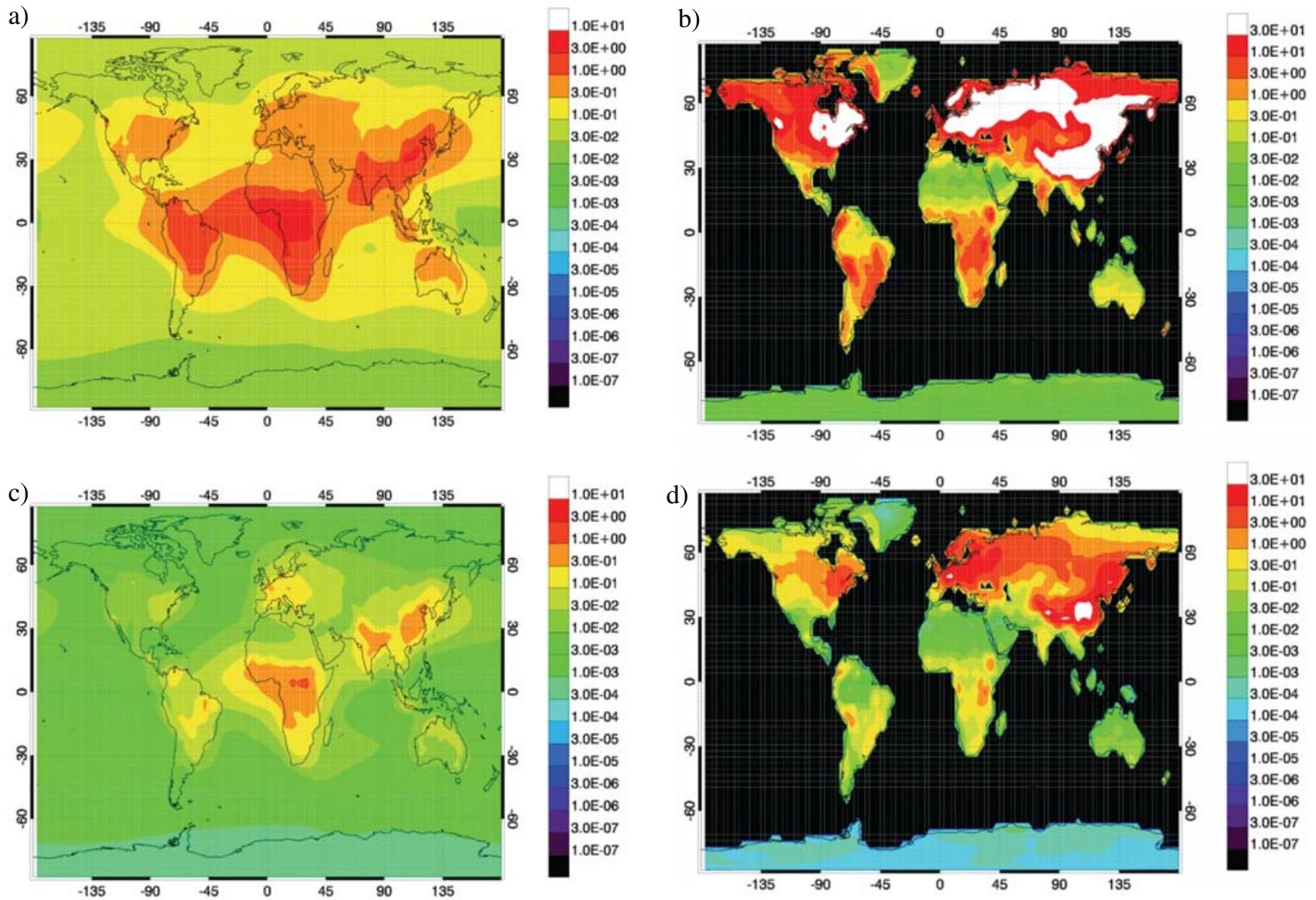

Fig. 2. Distributions of annual mean fluoranthene (FLT, a, c) and benzo(a)pyrene (BAP, b, d) burdens ( $\mu$ g $\mathrm{m}^{-2}$ ) in air (a, b) and soil (c, d) under the scenario assuming both absorption in organic matter and adsorption to soot to contribute to gas-particle partitioning (OB, see above 2.3 ). ${ }^{29}$ 
the hydroxyl radical, and of particle-associated PAH molecules) should be closed and the uncertainty of emission factors for some sources (e.g., biomass burning ${ }^{30}$ ) need to be reduced. Phase information from field data requires artefact-free sampling, which is not commonly used, ${ }^{41-42}$ or an in situ determination and quantification method, which is not yet available for ambient conditions (except for the parameter sum of $\mathrm{PAHs}^{43}$ ).

\section{Acknowledgements}

This manuscript follows an International Health Forum Lecture given at U Ljubljana, 2011. We thank Mirko Bizjak, Environmental Agency, Ljubljana, and Blaž Ivanc, U Ljubljana. This research was supported by the German Research Foundation (DFG project No. GR 660/15), the Granting Agency of the Czech Republic (GACR project No. P503/11/1230), and the Ministry of Education of the Czech Republic (LM2011028 and LO1214).

\section{References}

1. G. Lammel, Polycyclic Arom. Comp. 2015, http://dx.doi.org/10.1080/10406638.2014.931870

2. B. J. Finlayson-Pitts, J. N. Pitts: Chemistry of the Upper and Lower Atmosphere: Theory, Experiments, Application, Academic Press, San Diego, USA, 2000.

3. European Commission Polycyclic Aromatic Compounds Working Group: Ambient air pollution by polycyclic aromatic compounds (PAHs) - position paper, European Commission, Brussels, 2001.

4. J. F. Pankow, T. F. Bidleman, Atmos. Environ. 1991, 25A, 2241-2249. http://dx.doi.org/10.1016/0960-1686(91)90099-S

5. I. J. Keyte, R. M. Harrison, G. Lammel, Chem. Soc. Rev. 2013, 42, 9333-939. http://dx.doi.org/10.1039/c3cs60147a

6. T. E. M. ten Hulscher, L. E. V. D. Velde, W. A. Brueggeman, Environ. Toxicol. Chem. 1992, 11, 1595-1603. http://dx.doi. org/10.1897/1552-8618(1992)11[1595:TDOHLC]2.0.CO;2

7. W. Estève, H. Budzinski, E. Villenave, Atmos. Environ. 2004, 38, 6063-6072.

http://dx.doi.org/10.1016/j.atmosenv.2004.05.059

8. EPI Suite v4.0, Exposure assessment tools and models, US Environmental Protection Agency, http://www.epa.gov/opt/ exposure/pubs/episuitedl (assessed: March 31, 2013).

9. M. S. Zedeck, J. Environ. Pathol. Toxicol. 1980, 3, 537-567.

10. G. Lammel, J. Novák, L. Landlová, A. Dvorská, J. Klánová, P. Čupr, J. Kohoutek, E. Reimer, L. Škrdlíková, in: F. Zereini, C. L. S. Wiseman (Eds.): Urban Airborne Particulate Matter: Origins, Chemistry, Fate and Health Impacts, Springer, Berlin, 2010, pp. 39-62.

http://dx.doi.org/10.1007/978-3-642-12278-1_3

11. WHO: Health risks of persistent organic pollutants from longrange transboundary air pollution. World Health Organization Regional Office for Europe, Copenhagen, 2002, 252 pp.
12. J. L. Jaffrezo, M. P. Clain, P. Masclet, Atmos. Environ. 1994, 28, 1139-1145. http://dx.doi.org/10.1016/1352-2310(94)90291-7

13. P. Fernández, J. O. Grimalt, R. M. Vilanova, Environ. Sci. Technol. 2002, 36, 1162-1168. http://dx.doi.org/10.1021/es010190t

14. A. M. Sehili, G. Lammel, Atmos. Environ. 2007, 41, 83018315. http://dx.doi.org/10.1016/j.atmosenv.2007.06.050

15. C. Friedman, N. Selin, Environ. Sci. Technol. 2012, 46, 9501-9510. http://dx.doi.org/10.1021/es301904d

16. J. Franklin, R. Atkinson, P. H. Howard, J. J. Orlando, C. Seigneur, T. J. Wallington, C. Zetzsch, in: G. Klečka et al., (Eds.), Criteria for Persistence and Long-Range Transport of Chemicals in the Environment, SETAC Press, Pensacola, USA, 2001, pp. 7-62.

17. U. Pöschl, T. Letzel, C. Schauer, R. Niessner, J. Phys. Chem. A 2001, 105, 4029-4041. http://dx.doi.org/10.1021/jp004137n

18. J. Klánová, P. Čupr, J. Kohoutek, T. Harner T., Environ. Sci. Technol. 2008, 42, 550-555. http://dx.doi.org/10.1021/es072098o

19. P. Kukučka, G. Lammel, A. Dvorská, J. Klánová, A. Möller, E. Fries, Environ. Chem. 2010, 7, 504-513. http://dx.doi.org/10.1071/EN10066

20. I. Holoubek, J. Klánová, J. Jarkovský, J. Kohoutek, J. Environ. Mon. 2007, 9, 557-563. http://dx.doi.org/10.1039/b700750g

21. G. Lammel, J. Klánová, J. Kohoutek, R. Prokeš, L. Ries, A. Stohl, Environ. Pollut. 2009, 157, 3264-3271. http://dx.doi.org/10.1016/j.envpol.2009.05.028

22. G. Lammel, J. Klánová, P. Ilić, J. Kohoutek, B. Gasić, I. Kovacić, N. Lakić, R. Radić, Atmos. Environ. 2010, 44, 50155021. http://dx.doi.org/10.1016/j.atmosenv.2010.07.034

23. R. R. Draxler, G. D. Rolph: HYSPLIT (HYbrid Single-Particle Lagrangian Integrated Trajectory) Model access via NOAA ARL READY Website (http://www.arl.noaa.gov/ ready/hysplit4.html). NOAA Air Resources Laboratory, Silver Springs, USA, 2003.

24. G. Lammel, E. Brüggemann, T. Gnauk, K. Müller, C. Neusüss, A. Röhrl, J. Aerosol Sci. 2003, 34, 1-25. http://dx.doi.org/10.1016/S0021-8502(02)00134-9

25. A. Dvorská, G. Lammel, I. Holoubek, Atmos. Environ. 2009 , 43, 1280-1287. http://dx.doi.org/10.1016/j.atmosenv.2008.11.028

26. A. Stohl, M. Hittenberger, G. Wotawa, Atmos. Environ. 1998, 32, 4245-4264. http://dx.doi.org/10.1016/S1352-2310(98)00184-8

27. P. Stier, J. Feichter, S. Kinne, S. Kloster, E. Vignati, J. Wilson, L. Ganzeveld, I. Tegen, M. Werner, M. Schulz, Y. Balkanski, O. Boucher, A. Minikin, A. Petzold, Atmos. Chem. Phys. 2005, 5, 1125-1156. http://dx.doi.org/10.5194/acp-5-1125-2005

28. V. S. Semeena, J. Feichter, G. Lammel, Atmos. Chem. Phys. 2006, 6, 1231-1248. http://dx.doi.org/10.5194/acp-6-1231-2006

29. G. Lammel, A. M. Sehili, T. C. Bond, J. Feichter, H. Grassl, 
Chemosphere 2009, 76, 98-106.

http://dx.doi.org/10.1016/j.chemosphere.2009.02.017

30. G. Lammel, A. Heil, I. Stemmler, A. Dvorská, J. Klánová, Environ. Sci. Technol. 2013, 47, 11616-11624.

http://dx.doi.org/10.1021/es401499q

31. T. C. Bond, D. G. Streets, K. F. Yarber, S M. Nelson, J. H. Woo, Z. Klimont, J. Geophys. Res. 2004, 109, D14203, http://dx.doi.org/10.1029/2003JD003697.

32. J. F. Pankow, Atmos. Environ. 1987, 21, 2275-2283. http://dx.doi.org/10.1016/0004-6981(87)90363-5

33. R. Lohmann, G. Lammel, Environ. Sci. Technol. 2004, 38, 3793-3803. http://dx.doi.org/10.1021/es035337q

34. R. Lohmann, G. L. Northcott, K. C. Jones, Environ. Sci. Technol. 2000, 34, 2895-2899.

35. H. Herrmann, E. Brüggemann, U. Franck, T. Gnauk, G. Löschau, K. Müller, A. Plewka, G. Spindler, J. Atmos. Chem. 2006, 55, 103-130. http://dx.doi.org/10.1007/s10874-006-9029-7

36. R. M. Kamens, Z. Guo, J. N. Fulcher, D. A. Bell, Environ.
Sci. Technol. 1988, 22, 103-108. http://dx.doi.org/10.1021/es00166a012

37. A. Dvorská, G. Lammel, J. Klánová, Atmos. Environ. 2011, 45, 420-427. http://dx.doi.org/10.1016/j.atmosenv.2010.09.063

38. M. Hippelein, M. S. McLachlan, Environ. Sci. Technol. 1998, 32, 310-316. http://dx.doi.org/10.1021/es9705699

39. A. Bozlaker, A. Muezzinoglu, M. Odabasi, J. Hazard. Mat. 2008, 153, 1093-1102. http://dx.doi.org/10.1016/j.jhazmat.2007.09.064

40. J. Klánová, P. čupr, I. Holoubek, J. Borùvková, P. Přibylová, R. Kareš, T. Tomšej, T. Ocelka, J. Environ. Mon. 2009, 11, 1952-1163. http://dx.doi.org/10.1039/b913415h

41. M. Tsapakis, E. G. Stephanou, Atmos. Environ. 2003, 37, 4935-4944. http://dx.doi.org/10.1016/j.atmosenv.2003.08.026

42. C. Schauer, R. Niessner, U. Pöschl, Environ. Sci. Technol. 2003, 37, 2861-2868. http://dx.doi.org/10.1021/es034059s

43. K. A. Pratt, K. A. Prather, Mass Spectr. Rev. 2012, 31, 17-48. http://dx.doi.org/10.1002/mas.20330

\section{Povzetek}

Kljub dejstvu, da se navzočnost policikličnih aromatskih ogljikovodikov (PAH) v atmosferi raziskuje že desetletja, pa je fotokemija, njihovo odlaganje in s tem posledično potencial prenosa na dolge razdalje (LRTP) še vedno dokaj nepojasnjen. Razlogi so porazdelitev PAH-ov plin-trdno (GPP) v aerosolu, njihova občutljivost na temperaturo in sestavo trdnih delcev (aerosolov), pa tudi artefakti vzorčenja in občutljivost reaktivnosti napram sestavi trdnih delcev. Nadalje je večina PAH-ov pri odlaganju na površje podvržena ponovnemu izhlapevanju (ang. multihopping). Nivoji in izvori nesubstituiranih PAH-ov z 2-6 obroči so bili raziskani v oddaljenih okoljih Evrope, Afrike in Antarktike. Globalni transport v atmosferi in usoda PAH-ov s 3-5 obroči so bili simulirani pri različnih scenarijih GPP in fotokemije. GPP izrazito vpliva na življensko dobo PAH-ov v atmosferi, njihovo porazdelitev po različnih okoljskih sistemih in prenos na dolge razdalje. Emisije v srednji zemljepisni širini dosežejo Arktiko, ne pa tudi Antarktike. 